

\title{
Tinea capitis in children: a systematic review of management
}

\author{
A.K. Gupta ${ }^{1,2}$ R.R. Mays ${ }^{1}$ S.G. Versteeg ${ }^{1}$ B.M. Piraccini ${ }^{3}$ N.H. Shear ${ }^{5,6}$ V. Piguet ${ }^{4,5,6}$ A. Tosti \\ S.F. Friedlander ${ }^{8}$
}

1. Mediprobe Research Inc, London Canada

2. Department of Medicine, University of Toronto School of Medicine, Toronto, Canada

3. Department of Experimental, Diagnostic and Specialty Medicine, University of Bologna, Italy

4. Division of Infection \& Immunity, Cardiff University School of Medicine, Cardiff.

5. Division of Dermatology Women's College Hospital Toronto Canada.

6. Division of Dermatology, Dept of Medicine, University Toronto Canada

7. Fredric Brandt Endowed Professor of Dermatology, University of Miami, USA

8. University of California San Diego School of Medicine USA

\section{ABSTRACT \\ Background}

Tinea capitis is the most common cutaneous fungal infection in children.

\section{Objectives}

This review aims to evaluate the differences that exist between medications for the treatment of tinea capitis, to determine whether there are any significant adverse effects associated and to define the usefulness of sample collection methods.

\section{Methods}

We conducted a systematic literature search of available papers using the databases PubMed, OVID, Cochrane Libraries and ClinicalTrials.gov. 21 RCTs and 17 CTs were found.

\section{Results}

Among the different antifungal therapies (oral and combination thereof), continuous itraconazole and terbinafine had the highest mycological cure rates ( $79 \%$ and $81 \%$, respectively), griseofulvin and terbinafine had the highest clinical cure rates (46\% and 58\%, respectively) and griseofulvin and terbinafine had the highest complete cure rate (72\% and $92 \%$, respectively). Griseofulvin more effectively treated Microsporum infections; terbinafine and itraconazole more effectively cured Trichophyton infections. Only $1.0 \%$ of children had to discontinue medication based on adverse events. T. tonsurans was the most common organism found in North America, and hairbrush collection method is the most efficient method of sample collection. Additionally, using a hairbrush, toothbrush or cotton swab to identify the infecting organism(s) is the least invasive and most efficient method of tinea capitis sample collection in children. 


\section{Conclusions}

Current dosing regimens of reported drugs are effective and safe for use in tinea capitis in children.

\section{INTRODUCTION}

Tinea capitis is a superficial cutaneous fungal infection or dermatophytosis of the scalp also referred to as ringworm. The infection originates from a variety of sources including humans, animals and soil. It remains the most common cutaneous fungal infection in children, most prevalent between 3 and 7 years of age. ${ }^{1}$ The diagnosis of tinea capitis is made by a focused history, physical examination, trichoscopy and microscopy test. Methods of sample collection for microscopy diagnosis vary among location and investigator. The epidemiological distribution of tinea capitis has diverse geographical and seasonal variations depending on several factors, including lifestyle, population, migration of people and climatic conditions. This review aims to evaluate the differences between medications for the treatment of tinea capitis, to determine whether there are any significant adverse effects associated with this treatment and to determine the usefulness of the different diagnosing methods.

\section{METHODS}

\section{Search strategy and selection criteria}

A systematic review examined randomized controlled trials (RCTs) and clinical trials of tinea capitis in children. No date ranges were set. Potentially relevant studies were identified through a literature search for articles published as of 1 June 2017, using multiple research databases (PubMed, Ovid, Scopus, Cochrane libraries and ClinicalTrials.gov). The search identified any citations containing 'tinea capitis' or 'ringworm of the scalp' and 'children, child or children, childhood or paediatric or young'. Additional limits included removing duplicates, and searches were limited to English only articles, humans and children aged 18 years or younger. References within retrieved articles were also searched to identify additional articles that may have been missed in the primary database search.

\section{Study eligibility}

Studies were selected for analysis if the following criteria were met: (a) clinical trial (CT) or RCT (b) participants were 18 years of age or younger; (c) tinea capitis was clinically (as defined by investigators) and mycologically (as defined by mycological testing) diagnosed and (d) reported efficacy rates (e.g. mycological cure, clinical cure, complete cure) and/or safety measures. Papers which met explicit inclusion criteria were included for full-text review.

\section{Evaluation of efficacy}

Primary measures were efficacy rates examined across eligible studies and included mycological cure, clinical cure and complete cure. Mycological cure was defined as negative mycological testing (e.g. negative culture, negative potassium hydroxide (KOH), periodic acid-Schiff stain (PAS)). Clinical cure was defined as the absence of signs and symptoms of tinea capitis (could be Total Signs and Symptoms (TSSS) score of 0 or a clinical parameter score of 0 ). Complete cure was defined as both mycological and 
clinical cure. The TSSS is a scale that rates the severity of 5 different signs and symptoms (erythema, desquamation/scaling, papules, pustules and pruritus) on a 4-point scale (0, absent; 1 , mild; 2 , moderate; 3 , severe). These were summed to obtain a TSSS, with a maximum value of 15 points. $\underline{2}$ Secondary measures were qualitative evaluation of frequency and severity of reported adverse events and were obtained for each antifungal drug across all included studies. Study characteristics such as the year, location, method of collecting samples for investigation and infecting organisms were also reported and analysed.

\section{RESULTS}

\section{Study characteristics}

Our search yielded 4190 studies (Figure 1). The most common organisms found in each continent were T. violaceum in Africa,,$-\underline{3}$ M. canis in Asia, $\underline{6}-\underline{10}$ M. canis in Europe, $\underline{11-22}$ T. tonsurans in North America,$\underline{53}-\underline{37}$ and $M$. canis in South America $\underline{5}, \underline{38}, \underline{39}$ (Fig. 2). The most common hair sample collection method was the Wood's light examination/light microscopic examination $(9 / 18), \underline{3}, \underline{4}, \underline{15}, \underline{17}, \underline{18}, \underline{22}, \underline{33}, \underline{36}$ (Table $\underline{1}$ ). Across all studies, five oral antifungals (terbinafine, griseofulvin, itraconazole, ketoconazole and fluconazole) were examined in 3998 children. $-\underline{4} \underline{0}, \underline{13}-\underline{18}, 2 \underline{20}, \underline{21}, \underline{24}, \underline{25}, \underline{27}-\underline{29}, \underline{32}-$ 40 A few included studies also evaluated the efficacy and safety of combinations of oral and topical therapies across a total of 833 treated children $\underline{11}, \underline{12}, \underline{18}, \underline{19}, \underline{22}, \underline{23}, \underline{26}, \underline{30}, \underline{31}$ and 25 children used only topical therapies. $\frac{3}{}$

\section{Efficacy rates}

Terbinafine was evaluated in twelve included studies using weighted averages $\underline{4}, \underline{7}-\underline{10}, \underline{15}, \underline{16}, \underline{20}, \underline{24}, \underline{37}-\underline{39}$ with a pooled total of 1592 children (Table 2). Using the predefined definition of mycological cure (negative mycological testing) and after one or 2 weeks of treatment, terbinafine had a weighted average of $53.8 \%$ (57/106) children mycologically cured. Mycological cure after 4 weeks of treatment was $81.4 \%$ (48/59) and after six to 8 weeks of treatment 50.9\% (535/1052). Clinical cure was 58.1\% (50/86) and was evaluated in one study after one to 2 weeks of treatment. After one or 2 weeks of treatment, the average was $54.8 \%$ (57/104), and after 4 weeks of treatment, the average measured at week 6 was $91.7 \%(22 / 24)$, at week 8 was $69.4 \%(25 / 36)$ and then week 12 post-treatment was $60.9 \%(42 / 69)$.

Twelve studies examined the effects of griseofulvin. ${ }^{6,7,9,13-15,24,25,28, ~ 29, ~ 38, ~} 40$ The mycological cure after 6 weeks of treatment was a weighted average of 51.5\% (421/818) and after 8 weeks of treatment was $67.2 \%$ (43/64). The clinical cure after 6 weeks of treatment was a weighted average of $46.6 \%$ (373/801). Complete cure had a weighted average after 6 weeks of treatment of 32.8\% (263/801) and after 8 weeks the average increased to $71.8 \%(46 / 64)$.

Itraconazole continuous therapy was found in two studies, ${ }^{17,35}$ and the weighted average of the mycological cure at 12 weeks of the capsules is $79.0 \%$ (83/105). Ketoconazole was found in four 
studies, $^{14,25,28,29}$ and the weighted average of the mycological cure measured at 12 weeks was $15.1 \%$ $(11 / 73)$.

Terbinafine for 4 weeks was combined with either selenium sulphide shampoo ${ }^{11}$ or $1 \%$ terbinafine cream $^{22}$ for a mycological cure weighted average of $46.8 \%$ (61/126). Griseofulvin plus ciclopirox or selenium sulphide shampoo had a mycological cure weighted average of 32.7\% (32/98). Itraconazole capsules plus selenium sulphide shampoo had a mycological cure weighted average of 79.1\% (53/67).

\section{Efficacy rates per species}

Nine RCTs $(9 / 21)^{3,4}, 7,11,15,24,26,28,39$ and nine CTs $(9 / 17)^{5,16,18-22,30,35}$ reported cure rates that met our inclusion criteria. The fungi genus Microsporum (canis and audouinii), an exophytic invasion, was identified in combination therapy, ${ }^{11,18,19,22}$ griseofulvin, ${ }^{15,24,38}$ fluconazole, ${ }^{5}$ itraconazole, ${ }^{35}$ terbinafine, $^{8}$ 15, 20, 24,38, 39 squalamine ${ }^{3}$ and ketoconazole.28 The fungi genus Trichophyton (tonsurans, violaceum, mentagrophytes, rubrum, schoelini and verrucosum), an endophytic invasion, was identified in

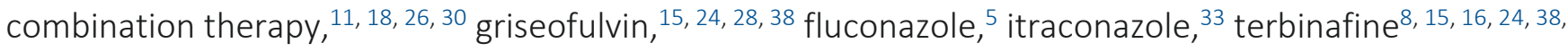
39 and ketoconazole. ${ }^{28}$ One RCT reported the species Penicillium and Scopulariopsis for the treatment with ketoconazole with only two participants and $100 \%$ mycological cure rate. ${ }^{28}$ One topical treatment squalamine was tested in the Microsporum species with none of the five participants cured. ${ }^{3}$

Griseofulvin more effectively treated Microsporum than Trichophyton infections (mycological cure rate $60 \%$ and $54 \%$, complete cure rate $49 \%$ and $40 \%$, respectively) (Table 3 ). This is further improved with the combination of selenium shampoo to oral griseofulvin (mycological cure 61\% and 31\%, respectively). Fluconazole was equally effective in treating both Microsporum and Trichophyton infections (mycological cure 94\% and 100\%, respectively). Lastly, Trichophyton infections were more effectively cured than Microsporumwith continuous itraconazole (mycological cure 91\% and 74\%, respectively) and terbinafine (mycological cure $66 \%$ and $46 \%$, complete cure $50 \%$ and $27 \%$, clinical cure $69 \%$ and $40 \%$, respectively).

\section{Adverse events reported}

A total of 295 adverse effects (AEs) from terbinafine 51.2\% (151/295), griseofulvin 26.8\% (79/295), fluconazole 12.2\% (36/295), itraconazole 8.5\% (25/295) and ketoconazole 1.4\% (4/295) related to drug use were reported (Table $\underline{3}$ ). No adverse events were considered life-threatening, and all were mild to moderate in severity and transient. Therefore, a total 318 children experienced some level of AEs related to drug use, at a frequency of $6.5 \%$ (318/4856). A total of 50 children ceased treatment $1.0 \%$ (50/4856) due to drug effects (Tables $\underline{4}$ and $\underline{5}$ ).

\section{DISCUSSION}

Among the 75 different combinations of antifungal therapies identified in our literature search, continuous itraconazole and terbinafine had the highest mycological cure rates; griseofulvin and 
terbinafine had the highest clinical cure rates; and griseofulvin and terbinafine had the highest complete cure rate. Adverse events were transient and limited to mild to moderate in severity. Griseofulvin more effectively treated Microsporum than Trichophyton infections. Fluconazole was reasonably equally effective in treating both Microsporum and Trichophyton infections. Finally, Trichophyton infections were more effectively cured than Microsporum with continuous itraconazole and terbinafine.

Traditionally, griseofulvin is the most widely prescribed medication for tinea capitis treatment in children, as it is one of the more cost-effective and accessible approaches. It is most effective for the treatment of Microsporum infections, but it is not available in paediatrics form in many countries. Table 6 outlines the paediatric drug availability per country. Microsized and ultramicrosized tablet versions of the drug show that co-administration of griseofulvin with fatty food will tend to reduce the difference between the bioavailability of the two types of preparations and microsized will be absorbed more easily. ${ }^{41}$ Griseofulvin is fungistatic and is quickly eliminated from the body so it must be continuously given for a long period of time to be effective. This longer duration of treatment may also contribute to a higher level of adverse events experienced compared to agents such as itraconazole, ketoconazole and fluconazole. A higher dose of griseofulvin is also needed for endothrix infections than ectothrix. This may contribute to the reduction in patient compliance and decreased efficacy, specifically in children. Griseofulvin, itraconazole and fluconazole are available as liquid suspensions, and fluconazole is also available as suppositories which are preferable methods of treatment for young children who are unable to swallow capsules and tablets. After puberty, the incidence of tinea capitis becomes more infrequent as an increase in fungistatic and fungicidal saturated lipid acids is associated with puberty. ${ }^{42}$

Azole antifungal agents itraconazole and fluconazole, as well as the allylamine agent terbinafine, have high affinity for keratinizing tissues, so these agents remain in keratin and hair for a period beyond the end of active dosing meaning dosage periods can be shorter than that of griseofulvin. Terbinafine for Microsporum infections needs to be given for a longer period of time, 6 to 8 weeks, compared to 4 weeks for Trichophyton infections. Oral terbinafine accounted for over half of the reported adverse events, possibly due to its extensive biodistribution. It is recommended that baseline transaminase is monitored in children taking terbinafine. ${ }^{43}$ A 2016 Cochrane review concluded that the best evidence suggests that these newer treatments (terbinafine, itraconazole and fluconazole) have comparable results to griseofulvin in children with tinea capitis caused by Trichophytonspecies. ${ }^{44}$ However, newer treatments are more expensive and as this is a fungal infection that generally infects the lower socioeconomical communities of the world.

Topical treatment may be useful as an adjunct to systemic therapy to decrease the carriage rate of infected species; however, oral treatment is necessary to effectively eradicate tinea capitis. ${ }^{45}$ Treatments such as selenium sulphide, ketoconazole or ciclopirox shampoo are not FDA-approved for 
tinea capitis specifically; however, (likely as they are ineffective on their own) it can be applied 2 to 3 times per week and left in place for 5 to 10 min for the duration of therapy or at least 2 weeks. ${ }^{45}$ Some experts recommend topical treatment is continued until clinical and mycological cure occurs. ${ }^{45}$ Mycological cure should be interpreted with caution, as the presence of a topical antifungal in a culture media would likely lead to a false negative result, so a clinical confirmation is necessary.

Bodyweight is used to determine drug dosing in most paediatric medicine to ensure a safe dose. Paediatric weight estimation methods have been varied due to problems with bias, precision and restrictions in the population to whom they can be applied. Physicians must rely on parental recall or provider estimation as strategies for estimating bodyweight or refer to the child's age or length. ${ }^{46}$ The effectiveness of these methods may be insufficient as most methods overestimate weight in children who are underweight and underestimate weight in children who are overweight or obese. ${ }^{46}$ Additionally, these methods may not take into account the race and ethnicity of children. ${ }^{46}$ More recent clinical trials have suggested that children require significantly larger weight-normalized doses to approximate the exposure estimates detected in adults. ${ }^{47}$

Trichophyton tonsurans is the most common aetiology in North America, and recent data show that it accounts for the rise in the prevalence of tinea capitis. T. tonsurans is an anthropophilic dermatophyte more likely to infect human skin and hair and can maintain viability for extended periods on inanimate objects such as combs, brushes, sheets and blankets. The highest incidence of infection occurs between the ages 3 and 7 years old, and boys and girls are equally affected. ${ }^{1}$ The continued rise of $T$. tonsurans as the primary cause of tinea capitis in North America can be attributed to a few factors. For one, the immigrant workers who have found their way into the USA, mostly from countries such as Mexico and Puerto Rico since the late 1890s, have been suspected to have carried the organism over the border. ${ }^{48}$ Additionally, many physicians still consider fluorescence (Wood's light examination) to be synonymous with tinea capitis, and $T$. tonsurans does not show up with fluorescence and may not contain the classic appearance of black dots. This means many cases of tinea capitis are misdiagnosed as other scalp conditions (seborrhoea, dandruff and impetigo) and often inadequately treated, leading to spread of the infection.

Microsporum canis is a zoophillic dermatophyte that causes infection carried by infected animals. It is the most common cause of tinea capitis in children in Europe, although cases due to anthropophilic dermatophytes such as M. audouinii, Trichophyton soudanense, Trichophyton violaceum are reported with increasing incidence since the 1990s.

Anthropophilic and zoophilic tinea capitis differ clinically, as the latter is characterized by more evident inflammatory changes. M. canis tinea capitis develops rapidly as a single round area of alopecia, with hair irregularly broken a few mm from the scalp, scales and erythema, associated with itching (Figure 3). The incidence is highest in hot months and history frequently reveals contact of the child with a wildcat. Tinea capitis due to anthropophilic dermatophytes, on the other hand, is often a chronic condition. 
Several small areas of alopecia due to hair broken at the scalp emergence (black dot tinea capitis) associated with mild scalp scaling are a typical feature (Figure 4). Scalp scaling associated or not with alopecia is found in family members, which should be checked and treated as they are asymptomatic carries. Trichoscopy confirms the diagnosis showing the typical features of tinea capitis, which vary depending on the hair type and not on the causative agent. ${ }^{49}$ Comma hairs, corkscrew hairs and morsecode hairs are exclusive typical findings (Figures 3,4).

Of the techniques included in our review, the fastest way to diagnose tinea capitis is microscopy which provides confirmation of the diagnosis and establishes whether the fungus is small-spore or large-spore ectothrix or endothrix; however, it is not always the most accurate. Direct microscopy will not yield species identification, whereas culturing the scrapings will express the species in the sample, but it will not distinguish causative agents from contaminants. Culturing the scrapings should be done to confirm diagnosis and provide precise identification of the species for epidemiologic purposes, even though this takes extended time (approximately 3 weeks, or longer). ${ }^{50}$ In the future, PCR-based techniques and DNA sequencings will be used more often as they are even faster than microscopy; they were not used in any of our included papers most likely due to the lack of availability of the necessary specialized equipment.

Over half of the studies in this review used some form of the Wood's light examination as a way to initially diagnose the infecting organism; this method is of little significance in western countries as the majority of infections are due to T. tonsurans, which does not fluoresce. In North Africa and Europe, Microsporum infections still dominate and Wood's light may still be useful as it is the least invasive method of organism identification (Figure 2). Hair clippings are not mentioned as a form of collecting the sample in our literature search, this is probably due to the fact that not all hair is long enough or not all children want a section of their hair to be clipped. The hairbrush method has the least invasive and most accurate sample collection process. The cotton swab method was mentioned by one paper ${ }^{38}$ and is similarly a good option as it is simple, inexpensive and useful for areas hard to scrape (eyelids, eyebrows) or areas that have lesions. The scalpel and hair plucking methods have better rates of identification; however, they are invasive specifically in children and particularly with active infected lesions. Diagnosis of inflammatory tinea capitis can sometimes be difficult as microscopy and even pathology might give negative results (Figures $5 a, b) .{ }^{51}$

Infection from fomites and hair care practices all play a role in the acquisition of tinea capitis due to anthropophilic dermatophytes. ${ }^{1}$ Predisposing factors of this type of tinea capitis include large family size, crowded living conditions and low socio-economic status. ${ }^{48,50,52}$ Individuals in contact with an infected person should be assessed for asymptomatic carriers of infection and may need to be treated to prevent spread of the infection. In case of tinea capitis by zoophilic dermatophytes, pets that may have carried the infection should be checked by a veterinarian, sampled by the toothbrush technique and treated accordingly, keeping in mind that cat can be asymptomatic carries of Microsporum canis. ${ }^{53}$ Fomites that may be infected should be discarded or disinfected with bleach or hot soapy water to 
prevent infection. Recent studies have indicated that it is impractical to keep children recently treated with oral therapy out of the classroom, particularly those in higher grade levels, because shedding of spores can occur for months, despite therapy. ${ }^{52}$ Tinea capitis, however, still remains a relatively rare entity among infants. One reference cites only 50 known reported cases of tinea capitis in infants less than 1 year of age at the time of their evaluation. ${ }^{54}$ Guidelines for infant care are not established.

In conclusion, the importance of early diagnosis and proper treatment for children with tinea capitis cannot be overstated as the psychosocial impact of permanent baldness in a child's life, and the overall lower quality of health is substantial. Current dosing regimens of reported drugs are effective and safe for use in tinea capitis in children. Wood's light should not be used as the only method of organism identification; this study recommends the use of hairbrushes, toothbrushes or cotton swabs as viable alternatives. 


\section{REFERENCES}

1. Michaels BD, Del Rosso JQ. Tinea capitis in infants: recognition, evaluation, and management suggestions. J Clin Aesthet Dermatol 2012; 5: 49-59

2. Friedlander SF, Aly R, Krafchik B et al. Terbinafine in the treatment of Trichophyton tinea capitis: a randomized, double-blind, parallel-group, duration-finding study. Pediatrics 2002; 109: 602-607.

3. Coulibaly $\mathrm{O}$, Thera MA, Koné AK et al. A double-blind randomized placebo-controlled clinical trial of squalamine ointment for tinea capitis treatment. Mycopathologia 2015; 179: 187-193.

4. Nejjam F, Zagula M, Cabiac MD, Guessous N, Humbert H, Lakhdar H. Pilot study of terbinafine in children suffering from tinea capitis: evaluation of efficacy, safety and pharmacokinetics. $\mathrm{Br} J$ Dermatol 1995; 132: 98-105.

5. Gupta AK, Dlova N, Taborda P et al. Once weekly fluconazole is effective in children in the treatment of tinea capitis: a prospective, multicentre study. Br J Dermatol 2000; 142: 965-968.

6. Dastghaib L, Azizzadeh M, Jafari P. Therapeutic options for the treatment of tinea capitis: griseofulvin versus fluconazole. J Dermatolog Treat 2005; 16: 43-46.

7. Deng $\mathrm{S}, \mathrm{Hu} \mathrm{H}, \mathrm{Abliz} \mathrm{P}$ et al. A random comparative study of terbinafine versus griseofulvin in patients with tinea capitis in Western China. Mycopathologia 2011; 172: 365-372.

8. Haroon TS, Hussain I, Aman $\mathrm{S}$ et al. A randomized double-blind comparative study of terbinafine for 1, 2 and 4 weeks in tinea capitis. Br J Dermatol 1996; 135: 86-88.

9. Khan SU, Khan AR, Wazir SM. Efficacy of terbinafine vs. Griseofulvin in tinea: capitis in the Northern areas of Pakistan. J Pak Assoc Dermatol 2011; 21: 281-284.

10. Ungpakorn R, Ayutyanont T, Reangchainam S, Supanya S. Treatment of Microsporum spp. tinea capitis with pulsed oral terbinafine. Clin Exp Dermatol 2004; 29: 300-303.

11. Fuller LC, Smith $\mathrm{CH}$, Cerio R et al. A randomized comparison of 4 weeks of terbinafine vs. 8 weeks of griseofulvin for the treatment of tinea capitis. Br J Dermatol 2001; 144: 321-327.

12. Grin El. A controlled trial of home versus hospital treatment of tinea capitis with griseofulvin. Bull World Health Organ 1965; 33: 193-196.

13. López-Gómez S, Del Palacio A, Van Cutsem J, Soledad Cuétara M, Iglesias L, Rodriguez-Noriega A. Itraconazole versus griseofulvin in the treatment of tinea capitis: a double-blind randomized study in children. Int J Dermatol 1994; 33: 743-747.

14. Martínez-Roig A, Torres-Rodríguez JM, Bartlett-Coma A. Double blind study of ketoconazole and griseofulvin in dermatophytoses. Pediatr Infect Dis J 1988; 7: 37-40.

15. Memişoğlu HR, Erboz S, Akkaya S et al. Comparative study of the efficacy and tolerability of 4 weeks of terbinafine therapy with 8 weeks of griseofulvin therapy in children with tinea capitis. $J$ Dermatolog Treat 1999; 10: 189-193.

16. De Freitas C, Marote J, Faria A, Fernandes A, Sequeira H, Rodrigo G. Tinea capitis in children of Canical, Madeira island, Portugal: isolation of an endemic focus of Trichophyton violaceum: treatment with terbinafine. J Dermatolog Treat 1998; 9: 247-249.

17. Ginter-Hanselmayer G, Smolle J, Gupta A. Itraconazole in the treatment of tinea capitis caused by Microsporum canis: experience in a large cohort. Pediatr Dermatol 2004; 21: 499-502.

18. Möhrenschlager M, Schnopp C, Fesq H et al. Optimizing the therapeutic approach in tinea capitis of childhood with itraconazole. Br J Dermatol 2000; 143: 1011-1015.

19. Haedersdal M, Svejgaard EL. Once-weekly fluconazole in children with tinea capitis due to Microsporum canis. Acta Derm Venereol 2005; 85: 177-178

20. Koumantaki E, Georgala S, Rallis E, Papadavid E. Microsporum canis tinea capitis in an 8-month-old infant successfully treated with 2 weekly pulses of oral itraconazole. Pediatr Dermato/2001; 18: 6062.

21. Koumantaki-Mathioudaki E, Devliotou-Panagiotidou D, Rallis E et al. Is itraconazole the treatment of choice in Microsporum canis tinea capitis? Drugs Exp Clin Res 2005; 31(Suppl): 11-15.

22. Silm H, Karelson M. Terbinafine: efficacy and tolerability in young children with tinea capitis due to Microsporum canis. J Eur Acad Dermatol Venereol 2002; 16: 228-230. 
23. Chen $\mathrm{C}$, Koch LH, Dice JE et al. A randomized, double-blind study comparing the efficacy of selenium sulfide shampoo $1 \%$ and ciclopirox shampoo $1 \%$ as adjunctive treatments for tinea capitis in children. Pediatr Dermatol 2010; 27: 459-462.

24. Elewski BE, Cáceres HW, DeLeon L et al. Terbinafine hydrochloride oral granules versus oral griseofulvin suspension in children with tinea capitis: results of two randomized, investigator-blinded, multicenter, international, controlled trials. J Am Acad Dermatol 2008; 59: 41-54.

25. Gan VN, Petruska M, Ginsburg CM. Epidemiology and treatment of tinea capitis: ketoconazole vs. griseofulvin. Pediatr Infect Dis J 1987; 6: 46-49.

26. Givens TG, Murray MM, Baker RC. Comparison of $1 \%$ and $2.5 \%$ selenium sulfide in the treatment of tinea capitis. Arch Pediatr Adolesc Med 1995; 149: 808-811.

27. Solomon BA, Collins R, Sharma R et al. Fluconazole for the treatment of tinea capitis in children. J Am Acad Dermatol 1997; 37: 274-275.

28. Tanz RR, Stag| S, Esterly NB. Comparison of ketoconazole and griseofulvin for treatment of tinea capitis in childhood: a preliminary study. Pediatr Emerg Care 1985; 1: 16-18.

29. Tanz RR, Hebert AA, Esterly NB. Treating tinea capitis: should ketoconazole replace griseofulvin? J Pediatr 1988; 112: 987-991.

30. Abdel-Rahman SM, Powell DA, Nahata MC. Efficacy of itraconazole in children with Trichophyton tonsurans tinea capitis. J Am Acad Dermatol 1998; 38: 443-446.

31. Lorch Dauk KC, Comrov E, Blumer JL, O'Riordan MA, Furman LM. Tinea capitis: predictive value of symptoms and time to cure with griseofulvin treatment. Clin Pediatr (Phila) 2010; 49: 280-286.

32. Montero-Gei F. Fluconazole in the treatment of tinea capitis. Int J Dermatol 1998; 37: 870-871.

33. Gupta AK, Alexis ME, Raboobee $\mathrm{N}$ et al. Itraconazole pulse therapy is effective in the treatment of tinea capitis in children: an open multicentre study. Br J Dermatol 1997; 137: 251-254.

34. Gupta AK, Solomon RS, Adam P. Itraconazole oral solution for the treatment of tinea capitis. Br J Dermatol 1998; 139: 104-106.

35. Gupta AK, Nolting S, de Prost $Y$ et al. The use of itraconazole to treat cutaneous fungal infections in children. Dermatology 1999; 199: 248-252.

36. Gupta AK, Adam P, Hofstader SL et al. Intermittent short duration therapy with fluconazole is effective for tinea capitis. Br J Dermatol 1999; 141: 304-306.

37. Krafchik B, Pelletier J. An open study of tinea capitis in 50 children treated with a 2-week course of oral terbinafine. J Am Acad Dermatol 1999; 41: 60-63.

38. Cáceres-Ríos H, Rueda M, Ballona R, Bustamante B. Comparison of terbinafine and griseofulvin in the treatment of tinea capitis. J Am Acad Dermatol 2000; 42: 80-84.

39. Filho ST, Cucé LC, Foss NT, Marques SA, Santamaria JR. Efficacy, safety and tolerability of terbinafine for Tinea capitis in children: Brazilian multicentric study with daily oral tablets for 1,2 and 4 weeks. $J$ Eur Acad Dermatol Venereol 1998; 11: 141-146.

40. Foster KW, Friedlander SF, Panzer H, Ghannoum MA, Elewski BE. A randomized controlled trial assessing the efficacy of fluconazole in the treatment of pediatric tinea capitis. J Am Acad Dermato/2005; 53: 798-809.

41. Bijanzadeh M, Mahmoudian M, Salehian P, Khazainia T, Eshghi L, Khosravy A. The bioavailability of griseofulvin from microsized and ultramicrosized tablets in nonfasting volunteers. Indian J Physiol Pharmacol 1990; 34: 157-161.

42. Rothman S, Smijanic AM, Weitkamp AW. Mechanism of spontaneous cure in puberty of ringworm of the scalp. Science 1946; 104: 201-203.

43. Patel D, Castelo-Soccio LA, Rubin Al, Streicher JL. Laboratory monitoring during systemic terbinafine therapy for pediatric onychomycosis. JAMA Dermatol 2017; 153: 1326-1327.

44. Chen $\mathrm{X}$, Jiang $\mathrm{X}$, Yang $\mathrm{M}$ et al. Systemic antifungal therapy for tinea capitis in children. Cochrane Database Syst Rev 2016; 12: CD004685.

45. Committee on Infectious Diseases, American Academy of Pediatrics. Red Book [Electronic Resource] : 2015 Report of the Committee on Infectious Diseases/Committee on Infectious Diseases, American Academy of Pediatrics, 13th edn. American Academy of Pediatrics, Elk Grove Village, Illinois, 2015. 
46. Abdel-Rahman SM, Ahlers N, Holmes A et al. Validation of an improved pediatric weight estimation strategy. J Pediatr Pharmacol Ther 2013; 18: 112-121.

47. Pan S, Zhu L, Chen M, Xia P, Zhou Q. Weight-based dosing in medication use: what should we know? Patient Prefer Adherence 2016; 10: 549-560.

48. Ajello L. Geographic distribution and prevalence of the dermatophytes. Ann N Y Acad Sci 1960; 89: 30-38.

49. Rudnicka L, Rakowska A, Kerzeja M, Olszewska M. Hair shafts in trichoscopy: clues for diagnosis of hair and scalp diseases. Dermatol Clin 2013; 31: 695-708.

50. Fuller LC, Child FC, Midgley G, Higgins EM. Scalp ringworm in south-east London and an analysis of a cohort of patients from a paediatric dermatology department. Br J Dermatol 2003; 148: 985-988.

51. LaSenna CE, Miteva M, Tosti A. Pitfalls in the diagnosis of kerion. J Eur Acad Dermatol Venereol2016; 30: 515-517.

52. Honig PJ. Tinea capitis: recommendations for school attendance. Pediatr Infect Dis J 1999; 18: 211214.

53. Pasquetti M, Min ARM, Scacchetti S, Dogliero A, Peano A. Infection by microsporum canis in paediatric patients: a veterinary perspective. Vet Sci 2017; 19: 4.

54. Gilaberte Y, Rezusta A, Gil J et al. Tinea capitis in infants in their first year of life. $\mathrm{Br} \mathrm{J}$ Dermato/2004; 151: 886-890.

55. Sporanox. Package Insert (Itraconazole) Capsules, 100 mg [Internet]. Drugs@ FDA: FDA Approved Drug Products. 2009.

56. Diflucan. Package Insert (Fluconazole) Tablets, 50, 100, 150, or 200 mg [Internet]. Drugs@FDA: FDA Approved Drug Products. 2011.

57. Nizoral. Package Insert (Ketoconazole) Tablets, 200 mg [Internet]. Drugs@FDA: FDA Approved Drug Products. 2013.

58. Gris-Peg. Package Insert (Griseofulvin Ultramicrosized) Tablets, 125 mg; 250 mg [Internet]. Drugs@FDA: FDA Approved Drug Products. 2016.

59. Lamisil. Package Insert: LAMISIL (terbinafine hydrochloride) Tablets, 250 mg Drugs@ FDA: FDA Approved Drug Products 2012 


\section{Figure 1}

Summary of literature search for RCTs and CTs on the treatment of tinea capitis in children

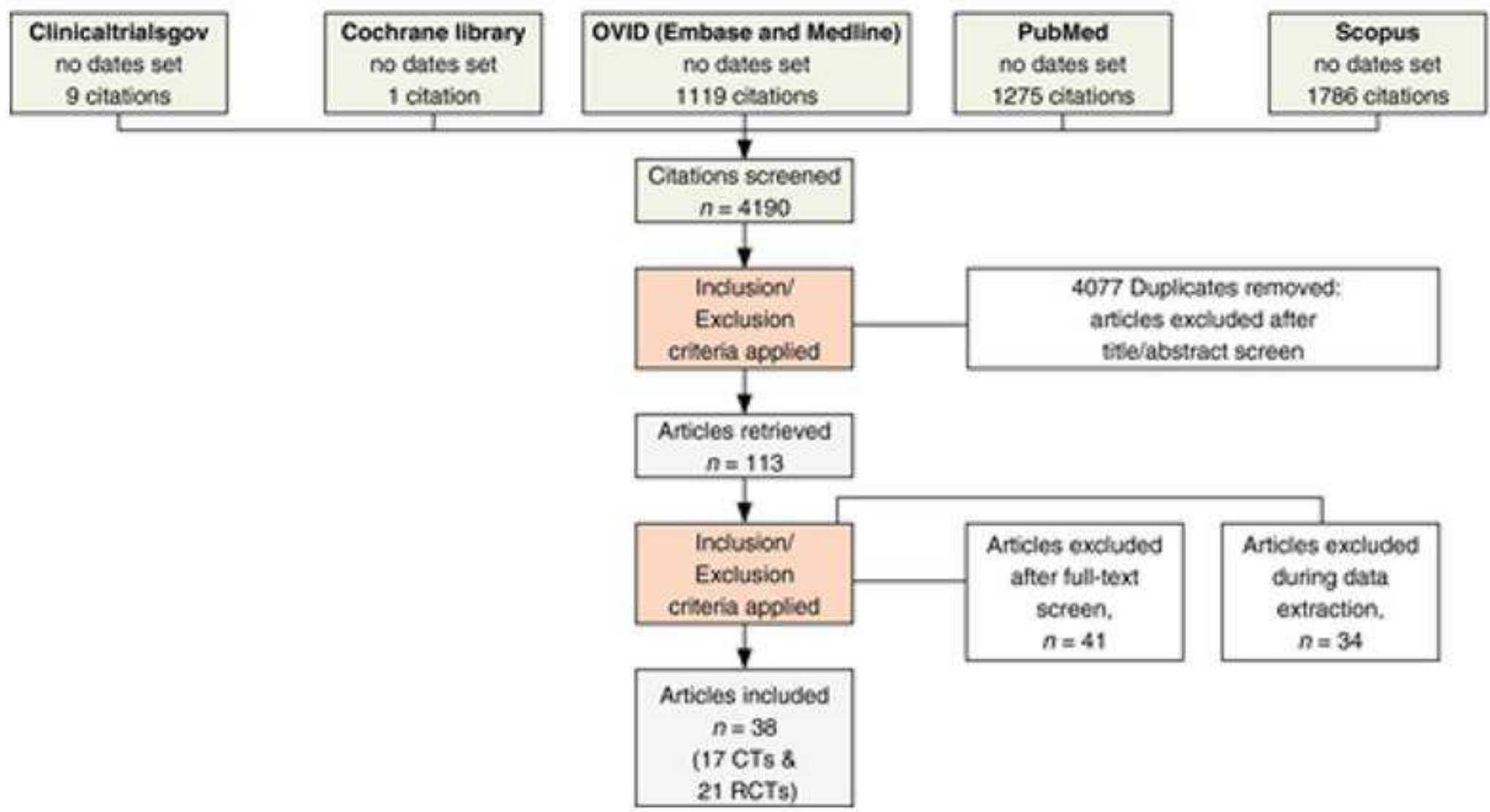




\section{Figure 2}

Map of most common organisms in each country. Countries in grey do not have sufficient information to include.

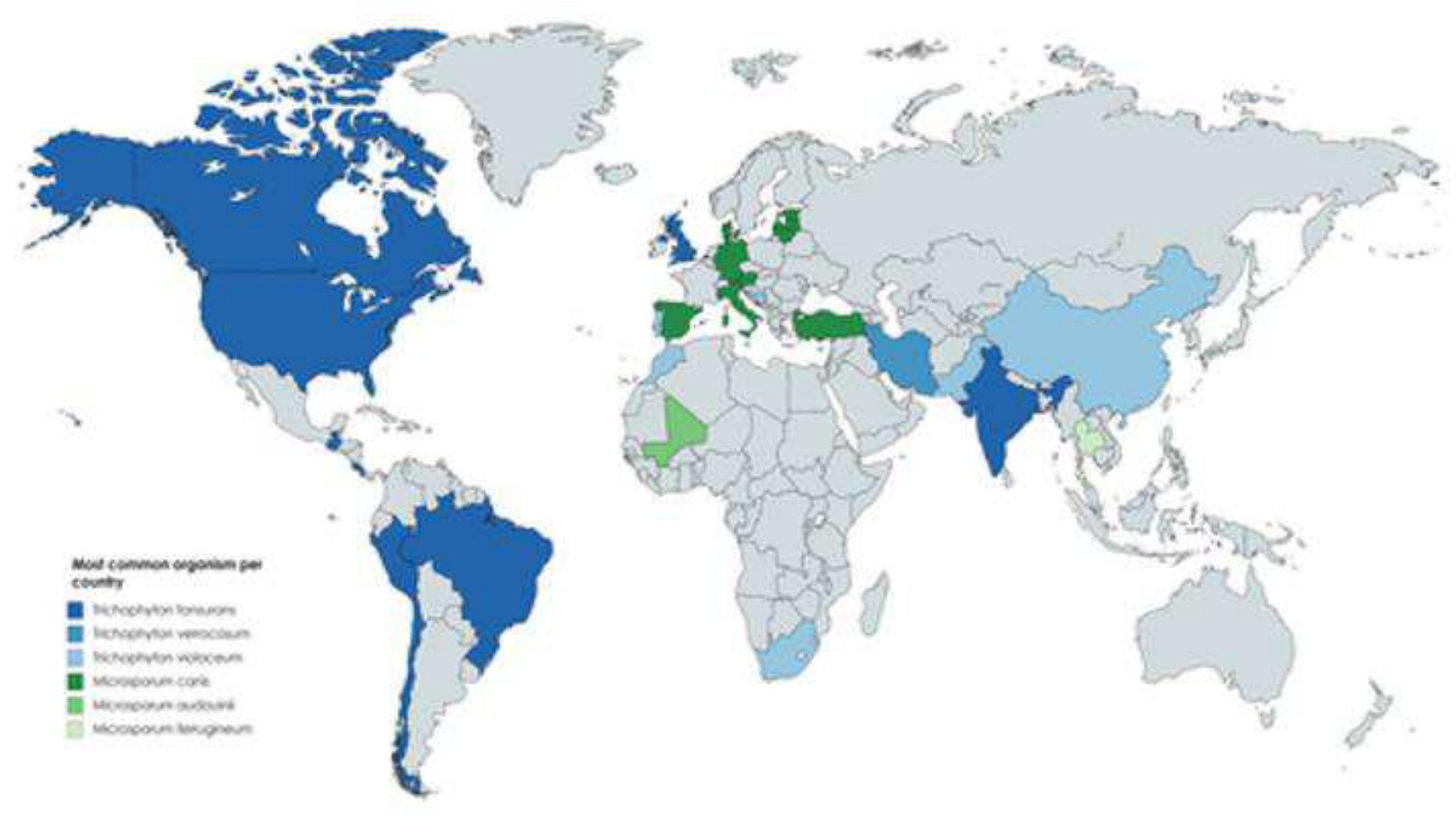




\section{Figure 3}

Tinea capitis due to Microsporum canis: scaly red patch of alopecia with broken hair shafts; trichoscopy shows coma hairs, morse-code hairs and hair casts.
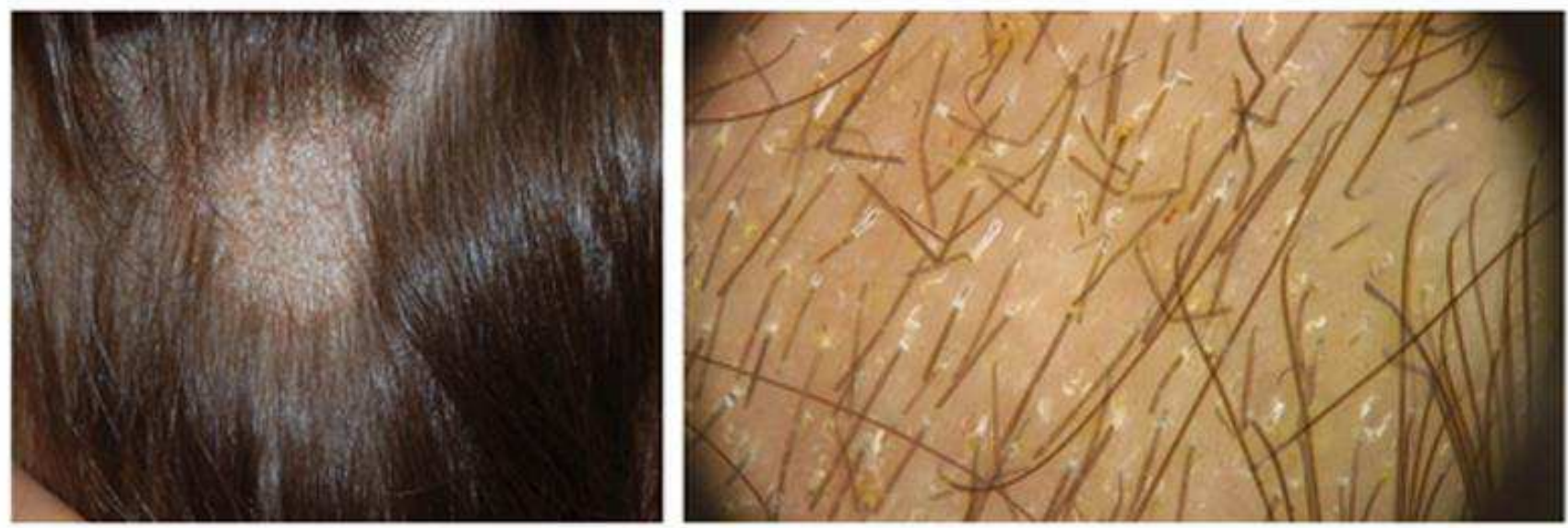


\section{Figure 4}

Tinea capitis due to Tricophyton tonsurans: scaly patches of alopecia; trichoscopy shows corkscrew hairs.
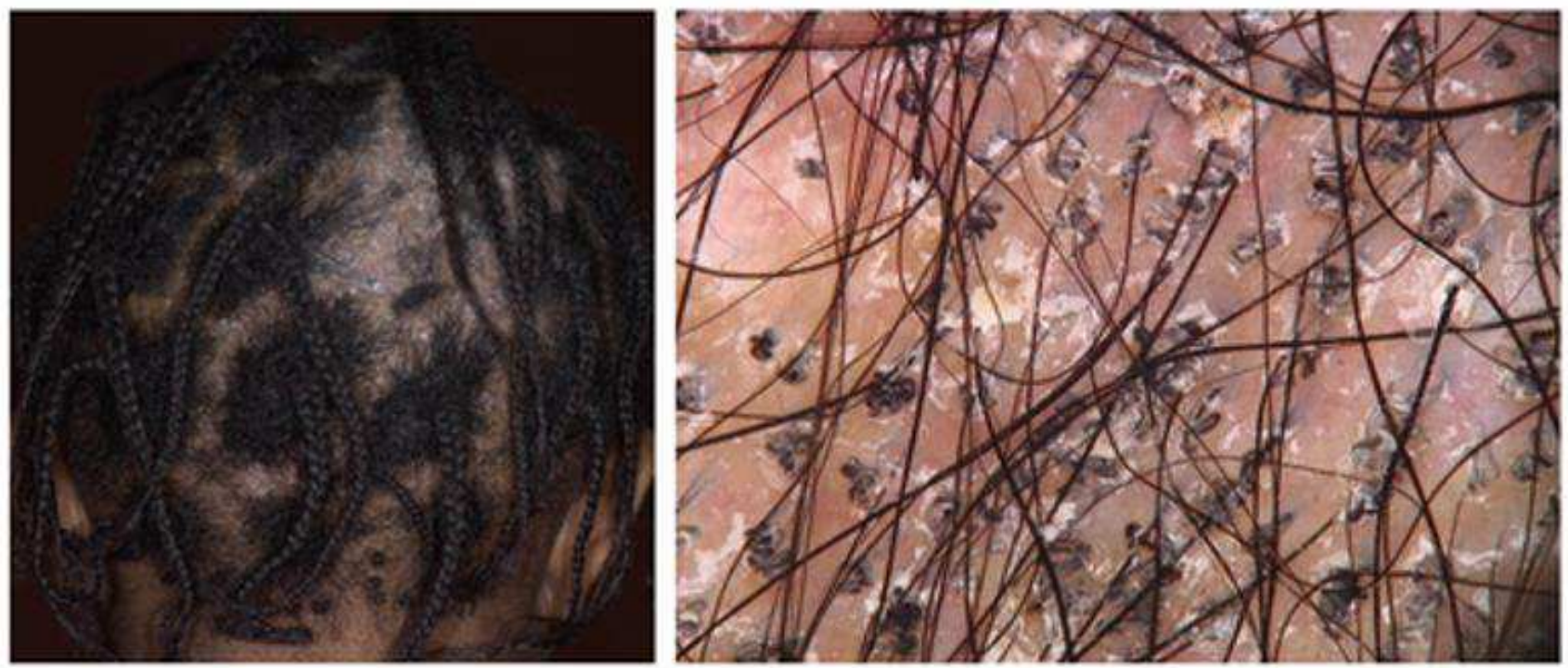


\section{Figure 5}

Kerion negative pathology and fungal staining.
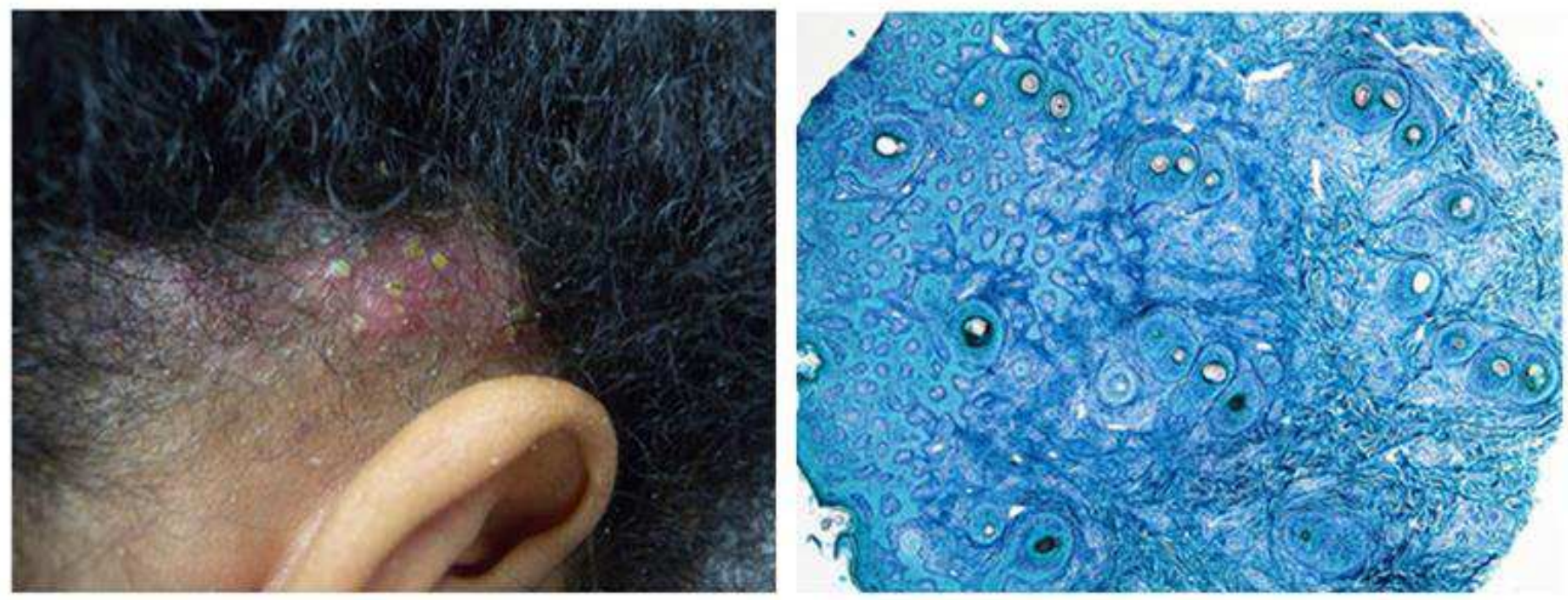
Table 1

Positives and negatives list of the methods of collection samples for the diagnosis tinea capitis in children

\begin{tabular}{|c|c|c|c|}
\hline Collection method & Technique & Positives & Negatives \\
\hline Cotton swabbing method ${ }^{14}$ & $\begin{array}{l}\text { A tap water, moistened sterile cotton tip } \\
\text { applicator is vigorously rubbed and } \\
\text { rotated over an affected area of scalp for } \\
\text { maximum } 15 \mathrm{~s}\end{array}$ & $\begin{array}{l}\text { - Cotton swabs are readily } \\
\text { available in most physicians' } \\
\text { offices } \\
\text { - Inexpensive } \\
\text { - Easy to use } \\
\text { - Useful for areas hard to } \\
\text { scrape (eyelids, eyebrows) or that } \\
\text { have lesions } \\
\text { - Low pain }\end{array}$ & $\begin{array}{l}\text { - Low efficacy in isolating the } \\
\text { dermatophytes from scalp } \\
\text { - Lack of ability to predict the spore } \\
\text { load } \\
\text { - Must scrub vigorously }\end{array}$ \\
\hline Hair clipping method & $\begin{array}{l}\text { A few hairs from involved areas of the } \\
\text { scalp are clipped from scalp }\end{array}$ & $\begin{array}{l}\text { - Hair clippers are readily } \\
\text { available in most physicians' } \\
\text { offices } \\
\text { - } \quad \text { Easy to use } \\
\text { - } \quad \text { No pain } \\
\text { - Inexpensive }\end{array}$ & $\begin{array}{l}\text { - Risking pain or trauma to the patient } \\
\text { - Not all hair can be clipped }\end{array}$ \\
\hline Hair plucking method 19,26 & $\begin{array}{l}\text { A few hairs from involved areas of the } \\
\text { scalp are plucked from scalp }\end{array}$ & $\begin{array}{l}\text { - Tweezers are readily available } \\
\text { in most physicians' offices } \\
\text { - Easy to use } \\
\text { - Inexpensive }\end{array}$ & $\begin{array}{l}\text { - Risking pain or trauma to the patient } \\
\text { - Not all hair can be plucked } \\
\text { - May remove uninvolved hairs }\end{array}$ \\
\hline Hairbrush culture technique ${ }^{3,56}$ & $\begin{array}{l}\text { Brush is rubbed on scalp. The friction } \\
\text { from massaging the bristles around the } \\
\text { affected areas makes the bristles } \\
\text { negatively charged so that they pick up } \\
\text { hairs and scalp scales. The brush is then } \\
\text { sent to the laboratory }\end{array}$ & $\begin{array}{l}\text { - Easy to use } \\
\text { - Brush covers a greater surface } \\
\text { area to collect samples } \\
\text { - Low pain }\end{array}$ & $\begin{array}{l}\text { - Hairbrushes are not readily available } \\
\text { in most physicians' offices } \\
\text { - Must scrub vigorously } \\
\text { - Isolation power at } 64 \% \\
\text { - Incubation period required for the } \\
\text { hairbrush culture is at least } 2 \text { week }\end{array}$ \\
\hline
\end{tabular}




\begin{tabular}{|c|c|c|c|}
\hline Collection method & $\underline{\text { Technique }}$ & Positives & Negatives \\
\hline & & & $\begin{array}{l}\text { - Poor results children with closely } \\
\text { cropped or shaved scalps, or tightly } \\
\text { braided hair }\end{array}$ \\
\hline Scalpel blade method & $\begin{array}{l}\text { Obtained by scraping the affected area } \\
\text { with the blunt side of a scalpel (to avoid } \\
\text { slicing through the infected hairs) onto a } \\
\text { piece of folded paper }\end{array}$ & $\begin{array}{l}\text { - } \quad \text { Can tests for } \mathrm{KOH} \text { easily } \\
\text { - } \quad \text { Scalpels are readily available } \\
\text { in most physicians' offices }\end{array}$ & $\begin{array}{l}\text { - Expensive } \\
\text { - Risking pain or trauma to the patient } \\
\text { - This technique requires some practice }\end{array}$ \\
\hline $\begin{array}{l}\text { Toothbrush culture } \\
\text { technique }^{11,15,37}\end{array}$ & $\begin{array}{l}\text { The friction from massaging the bristles } \\
\text { around the affected areas makes the } \\
\text { bristles negatively charged so that they } \\
\text { pick up hairs and scalp scales }\end{array}$ & $\begin{array}{l}\text { - Inexpensive } \\
\text { - Low pain }\end{array}$ & $\begin{array}{l}\text { - Low efficacy in isolating the } \\
\text { dermatophytes from scalp and their lack } \\
\text { of ability to predict the spore load } \\
\text { - Toothbrushes are not readily } \\
\text { available in most physicians' offices } \\
\text { - Provides greater inoculum for culture }\end{array}$ \\
\hline $\begin{array}{l}\text { Wood's light/lamp } \\
\text { examination }{ }^{4,10,16,20,38} \text { or light } \\
\text { microscopy examination }^{6,13,24,31}\end{array}$ & $\begin{array}{l}\text { Hair is examined and exposed to the } \\
\text { black light }\end{array}$ & $\begin{array}{l}\text { - No pain } \\
\text { - Easy to use }\end{array}$ & $\begin{array}{l}\text { - Expensive } \\
\text { - Not readily available in most } \\
\text { physicians' offices } \\
\text { - Can only detect Microsporum spp. } \\
\text { species with a blue-green fluoresce and } \\
\text { T. schoenleinii has a dull blue fluoresce }\end{array}$ \\
\hline
\end{tabular}


Table 2

Efficacy rates

\begin{tabular}{|c|c|c|c|}
\hline Dose & Mycological cure & Complete cure & Clinical cure \\
\hline \multicolumn{4}{|l|}{ Griseofulvin } \\
\hline Based on weight for 8 weeks & Wk 12: 67.2\% $(n=64)$ & $\begin{array}{l}\text { Wk 8: } 40.6 \%(n=64) \\
\text { Wk 12: } 71.8 \%(n=64)\end{array}$ & \\
\hline Based on weight for 6 weeks & $\begin{array}{l}\text { Wk 6: } 52.3 \%(n=321) \\
\text { Wk 10: } 51.5 \%(n=818)\end{array}$ & Wk 10: $32.8 \%(n=801)$ & Wk 10: $46.4 \%(n=801)$ \\
\hline $\begin{array}{l}\text { 10-15 mg/kg/day for } 8 \text { weeks } \\
\text { (plus ciclopirox or selenium } \\
\text { sulphide shampoo) }\end{array}$ & $\begin{array}{l}\text { Wk 2: } 16.7 \%(n=78) \\
\text { Wk 4: } 37.4 \%(n=155) \\
\text { Wk 6: } 44.4 \%(n=45) \\
\text { Wk 8: } 41.3 \%(n=155) \\
\text { Wk 12: 32.7\%(n=98) }\end{array}$ & & \\
\hline \multicolumn{4}{|l|}{ Itraconazole } \\
\hline $\begin{array}{l}100 \text { mg/day for } 4 \text { weeks (plus } \\
\text { selenium sulphide shampoo) }\end{array}$ & $\begin{array}{l}\text { Wk 4: } 55.2 \%(n=67) \\
\text { Wk 6: } 68.7 \%(n=67) \\
\text { Wk 8: } 79.1 \%(n=67)\end{array}$ & & \\
\hline $\begin{array}{l}3-5 \mathrm{mg} / \mathrm{kg} / \mathrm{day} \text { for } 4 \text { to } \\
8 \text { weeks }\end{array}$ & Wk 12: $79.0 \%(n=105)$ & & \\
\hline Ketoconazole & & & \\
\hline $\begin{array}{l}3.3-6.6 \mathrm{mg} / \mathrm{kg} / \mathrm{day} \text { for } \\
2 \text { weeks }\end{array}$ & $\begin{array}{l}\text { Wk 4: } 24.7 \%(n=73) \\
\text { Wk 12: } 15.1 \%(n=73)\end{array}$ & & \\
\hline
\end{tabular}




\begin{tabular}{|c|c|c|c|}
\hline \multicolumn{4}{|l|}{ Terbinafine } \\
\hline $\begin{array}{l}\text { Based on weight for } 1 \text { to } \\
2 \text { weeks }\end{array}$ & Wk 4: $53.8 \%(n=106)$ & Wk 12: $54.8 \%(n=104)$ & Wk 12: $58.1 \%(n=86)$ \\
\hline Based on weight for 4 weeks & $\begin{array}{l}\text { Wk 4: 66.3\% }(n=83) \\
\text { Wk 8: 69.6\% }(n=56) \\
\text { Wk 12: } 81.4 \%(n=59)\end{array}$ & $\begin{array}{l}\text { Wk 3: } 8.3 \%(n=24) \\
\text { Wk 6: } 91.7 \%(n=24) \\
\text { Wk 8: } 69.4 \%(n=36) \\
\text { Wk 12: } 60.9 \%(n=69)\end{array}$ & \\
\hline $\begin{array}{l}\text { Based on weight for } 6 \text { to } \\
8 \text { weeks }\end{array}$ & Wk 6: 50.9\% $(n=1052)$ & & \\
\hline $\begin{array}{l}\text { Based on weight for } 4 \text { weeks } \\
\text { plus selenium sulphide } \\
\text { shampoo or } 1 \% \text { terbinafine } \\
\text { cream }\end{array}$ & Wk 4: $46.8 \%(n=126)$ & Wk 4: 32.9\% $(n=158)$ & \\
\hline
\end{tabular}


Table 3

\begin{tabular}{|c|c|c|c|c|c|c|c|}
\hline \multicolumn{2}{|c|}{ Treatment (dosage) } & \multicolumn{2}{|l|}{ Mycological cure } & \multicolumn{2}{|l|}{ Complete cure } & \multicolumn{2}{|l|}{ Clinical cure } \\
\hline & & Microsporumspp. & Trichophytonspp. & Microsporumspp. & Trichophytonspp. & Microsporumspp. & Trichophytonspp. \\
\hline Griseofulvin & $\begin{array}{l}\text { Dose based on } \\
\text { wgt for } 6 \text { to } \\
8 \text { wks }\end{array}$ & $\begin{array}{l}\text { Wks } 8 \text { to } 12 \text { : } \\
60.0 \%(n=86)\end{array}$ & $\begin{array}{l}\text { Wks } 6 \text { to } 12 \text { : } \\
54.4 \%(n=388)\end{array}$ & $\begin{array}{l}\text { Wks } 8 \text { to } 12 \text { : } \\
48.5 \%(n=99)\end{array}$ & $\begin{array}{l}\text { Wks } 6 \text { to } 12 \text { : } \\
39.8 \%(n=357)\end{array}$ & $\begin{array}{l}\text { Wks } 8 \text { to } 12 \text { : } \\
57.3 \%(n=82)\end{array}$ & $\begin{array}{l}\text { Wks } 6 \text { to } 12 \text { : } \\
59.0 \%(n=339)\end{array}$ \\
\hline $\begin{array}{l}\text { Griseofulvin } \\
\text { plus selenium } \\
\text { sulphide } \\
\text { shampoo }\end{array}$ & $\begin{array}{l}10 \text { to } 15 \mathrm{mg} / \\
\mathrm{kg} / \mathrm{dy} \text { plus } 1 \text { to } \\
2.5 \% \text { for } 8 \mathrm{wks}\end{array}$ & $\begin{array}{l}\text { Wks } 4 \text { to } 24: 60.6 \% \\
(n=33)\end{array}$ & $\begin{array}{l}\text { Wks } 2 \text { to } 8: \\
30.7 \%(n=238)\end{array}$ & - & - & - & - \\
\hline Fluconazole & $\begin{array}{l}8 \mathrm{mg} / \mathrm{kg} / \mathrm{dy} \text { for } \\
8 \mathrm{wks}\end{array}$ & $\begin{array}{l}\text { Wks 8: } \\
94.1 \%(n=17)\end{array}$ & $\begin{array}{l}\text { Wks 8: } \\
100.0 \%(n=44)\end{array}$ & - & - & - & - \\
\hline Itraconazolea & $\begin{array}{l}3 \text { to } 5 \mathrm{mg} / \\
\mathrm{kg} / \mathrm{dy} \text { for } 4 \text { to } \\
8 \text { wks }\end{array}$ & $\begin{array}{l}\text { Wks } 4 \text { to } 6: 73.5 \% \\
(n=34)\end{array}$ & $\begin{array}{l}\text { Wks } 4 \text { to } 8: \\
90.9 \%(n=22)\end{array}$ & - & - & - & - \\
\hline $\begin{array}{l}\text { Itraconazolea } \\
\text { plus selenium } \\
\text { sulphide } \\
\text { shampoo }\end{array}$ & $\begin{array}{l}\text { Dose based on } \\
\text { wgt plus } 1 \text { to } \\
2.5 \% \text { for } 4 \text { wks }\end{array}$ & $\begin{array}{l}\text { Wks } 4 \text { to } 8: 93.6 \% \\
(n=78)\end{array}$ & $\begin{array}{l}\text { Wks } 2 \text { to } 8: 52.7 \% \\
(n=148)\end{array}$ & - & - & - & - \\
\hline Terbinafine & $\begin{array}{l}\text { Dose based on } \\
\text { wgt } 6 \text { to } 8 \text { wks }\end{array}$ & $\begin{array}{l}\text { Wks } 8 \text { to } 12: 45.9 \% \\
(n=170)\end{array}$ & $\begin{array}{l}\text { Wks } 8 \text { to } 12 \text { : } \\
66.4 \%(n=699)\end{array}$ & $\begin{array}{l}\text { Wks 10: } \\
27.0 \%(n=152)\end{array}$ & $\begin{array}{l}\text { Wks 10: } \\
49.5 \%(n=667)\end{array}$ & $\begin{array}{l}\text { Wks 10: } \\
39.5 \%(n=152)\end{array}$ & $\begin{array}{l}\text { Wks 10: } \\
68.8 \%(n=667)\end{array}$ \\
\hline $\begin{array}{l}\text { Terbinafine } \\
\text { plus selenium } \\
\text { sulphide } \\
\text { shampoo or } \\
\text { terbinafine } \\
\text { cream }\end{array}$ & $\begin{array}{l}\text { Dose based on } \\
\text { wgt plus } 1 \text { or } \\
2.5 \% \text { or } 1 \% \text { for } \\
4 \mathrm{wks}\end{array}$ & $\begin{array}{l}\text { Wks } 4 \text { to } 24: 26.1 \% \\
(n=115)\end{array}$ & $\begin{array}{l}\text { Wks } 4 \text { to } 8: \\
47.8 \%(n=67)\end{array}$ & - & - & - & - \\
\hline
\end{tabular}

a continuous itraconazole treatment.

Wk, week; Wgt, weight 
Table 4

\begin{tabular}{|c|c|c|c|c|c|c|c|c|}
\hline Drug & $\begin{array}{l}\frac{\text { Reported }}{\text { circulatory }} \\
\text { events }\end{array}$ & $\begin{array}{l}\frac{\text { Reported }}{\text { dermatological }} \\
\text { events }\end{array}$ & $\begin{array}{l}\text { Reported } \\
\text { gastrointestinal } \\
\text { events }\end{array}$ & $\begin{array}{l}\text { Reported } \\
\text { respiratory } \\
\text { events }\end{array}$ & $\begin{array}{l}\frac{\text { Reported }}{\text { miscellaneous }} \\
\text { events }\end{array}$ & $\begin{array}{l}\text { Total reported } \\
\text { drug related } \\
\underline{\text { events }}\end{array}$ & $\begin{array}{l}\text { Number of } \\
\text { children } \\
\text { experiencing } \\
\underline{\text { AEs }}\end{array}$ & $\begin{array}{l}\text { Number of } \\
\text { children disc. } \\
\text { drug due to } \\
\mathrm{AE}(n=)\end{array}$ \\
\hline $\begin{array}{l}\text { Fluconazole } \\
(n=758) \text { LFTa }\end{array}$ & - & $\operatorname{Rash}(3 / 36)$ & $\begin{array}{l}\text { AP }(6 / 36) \\
\text { Diarrhea }(4 / 36) \\
\text { Dyspepsia }(1 / 36) \\
\text { Gastritis }(4 / 36)\end{array}$ & $\begin{array}{l}\text { Fever }(3 / 36) \\
\text { Rhinitis }(1 / 36) \\
\text { URTI }(1 / 36) \\
\text { Otitis media } \\
(1 / 36) \\
\end{array}$ & $\begin{array}{l}\text { Headache }(5 / 36) \\
\text { Nausea }(3 / 36) \\
\text { Vomiting }(2 / 36) \\
\text { Unspecified }(2 / 36)\end{array}$ & 36 & $36 / 758$ & $10 / 758$ \\
\hline $\begin{array}{l}\text { Griseofulvin } \\
(n=1665) \text { None }^{a}\end{array}$ & $\begin{array}{l}\text { 个triglycerides } \\
(1 / 79)^{b} \\
\text { Anemia }(2 / 79) \\
\text { SGOT }(1 / 79)\end{array}$ & Rash (1/79) & $\begin{array}{l}\text { AP }(10 / 79) \\
\text { Diarrhea }(7 / 79) \\
\text { Dyspepsia }(3 / 79)\end{array}$ & Fever (1/79) & $\begin{array}{l}\text { Headache }(12 / 79) \\
\text { Nausea }(9 / 79) \\
\text { Weight gain }(3 / 79) \\
\text { Vomiting }(12 / 79) \\
\text { Unspecified }(17 / 79) \\
\end{array}$ & 79 & $83 / 1665$ & $15 / 1665$ \\
\hline $\begin{array}{l}\text { Itraconazole } \\
(n=521) \text { LFT initially and } \\
\text { after } 4 \text { wks of use }\end{array}$ & - & $\begin{array}{l}\text { Atopic } \\
\text { dermatitis (2/25) } \\
\text { Skin lesions } \\
(4 / 25)\end{array}$ & $\begin{array}{l}\text { AP }(2 / 25) \\
\text { Diarrhea (4/25) } \\
\text { General events } \\
\text { (3/25) } \\
\text { Indigestion } \\
(2 / 25) \\
\end{array}$ & $\begin{array}{l}\text { Viral infection } \\
(3 / 25) \\
\text { Epistaxis (1/25) }\end{array}$ & $\begin{array}{l}\text { Headache }(1 / 25) \\
\text { Vomiting }(3 / 25)\end{array}$ & 25 & $23 / 521$ & $4 / 521$ \\
\hline $\begin{array}{l}\text { Ketoconazole } \\
(n=169) \text { LFT initially and } \\
\text { after } 4 \text { wks of use }\end{array}$ & - & Urticaria (1/4) & $\operatorname{AP}(2 / 4)$ & - & Nausea (1/4) & 4 & $4 / 169$ & 0/169 \\
\hline $\begin{array}{l}\text { Terbinafine } \\
(n=1718) \text { LFT initially } \\
\text { and after } 6 \text { wks of use }\end{array}$ & $\begin{array}{l}\text { Eosinophilia } \\
(5 / 151) \\
\text { PVE (1/151) } \\
\uparrow \\
\text { triglycerides(5 } \\
/ 151)^{\mathrm{b}} \\
\uparrow \text { hepatic }^{-} \\
\text {enzymes(8/15 } \\
1^{\mathrm{b}} \mathrm{b} \\
\text { Leucytosis } \\
(4 / 151)\end{array}$ & $\begin{array}{l}\text { Erythema } \\
(1 / 151) \\
\text { Itch }(2 / 151) \\
\text { ID reaction } \\
(7 / 151) \\
\text { Pruritus }(1 / 151) \\
\text { Urticaria }(1 / 151)\end{array}$ & $\begin{array}{l}\text { AP (24/151) } \\
\text { Diarrhea } \\
(12 / 151) \\
\text { Obstipation } \\
(2 / 151)\end{array}$ & - & $\begin{array}{l}\text { Anorexia }(1 / 151) \\
\text { Headache }(12 / 151) \\
\text { Nausea }(13 / 151) \\
\text { Vomiting }(18 / 151) \\
\text { Weight gain }(4 / 151) \\
\text { Taste disorder } \\
\text { (2/151) } \\
\text { Unspecified } \\
(28 / 151)\end{array}$ & 151 & $172 / 1718$ & $21 / 1718$ \\
\hline
\end{tabular}




\begin{tabular}{|c|c|c|c|c|c|c|c|c|}
\hline Drug & $\begin{array}{l}\text { Reported } \\
\text { circulatory } \\
\text { events }\end{array}$ & $\begin{array}{l}\frac{\text { Reported }}{\text { dermatological }} \\
\text { events }\end{array}$ & $\begin{array}{l}\text { Reported } \\
\text { gastrointestinal } \\
\text { events }\end{array}$ & $\begin{array}{l}\text { Reported } \\
\text { respiratory } \\
\text { events }\end{array}$ & $\begin{array}{l}\text { Reported } \\
\text { miscellaneous } \\
\text { events }\end{array}$ & $\begin{array}{l}\text { Total reported } \\
\text { drug related } \\
\text { events }\end{array}$ & $\begin{array}{l}\text { Number of } \\
\text { children } \\
\text { experiencing } \\
\underline{\text { AEs }}\end{array}$ & $\begin{array}{l}\text { Number of } \\
\text { children disc. } \\
\text { drug due to } \\
\text { AE }(n=)\end{array}$ \\
\hline Topicals $(n=25)$ & - & - & - & - & - & 0 & $0 / 25$ & $0 / 25$ \\
\hline Total & & & & & & $\begin{array}{l}295 \\
\text { individual } \\
\text { events }\end{array}$ & $\begin{array}{l}318 / 4856 \\
(6.5 \%) \\
\text { children }\end{array}$ & $\begin{array}{l}50 / 4856 \\
(1.0 \%) \\
\text { children } \\
\text { disc. }\end{array}$ \\
\hline
\end{tabular}

a Recommened laboratory tests

${ }^{\mathrm{b}}$ Laboratory events recorded

LFT, Liver function test; URTI, Upper respiratory tract infection; PVE, Pruritic vesiculopustular eruption; AP, Abdominal pain; Disc., discontinued; wks, weeks. 
Table 5

\begin{tabular}{|c|c|c|}
\hline Drug & Dosage & Duration \\
\hline \multicolumn{3}{|l|}{ Tablets } \\
\hline Fluconazole & $6 \mathrm{mg} / \mathrm{kg} / \mathrm{day}$ & 3 and 6 weeks \\
\hline $\begin{array}{l}\text { Griseofulvin } \\
\text { - microsized } \\
\end{array}$ & $20-25 \mathrm{mg} / \mathrm{kg} /$ day & $\begin{array}{l}\geq 6 \text { weeks; continue until clinically } \\
\text { clear }\end{array}$ \\
\hline $\begin{array}{l}\text { Griseofulvin } \\
\text { - ultramicrosized }\end{array}$ & 10-15 mg/kg/day & $\begin{array}{l}\geq 6 \text { weeks; continue until clinically } \\
\text { clear }\end{array}$ \\
\hline Itraconazole & $5 \mathrm{mg} / \mathrm{kg} /$ day & $\begin{array}{l}\text { Trichophyton spp.: 2-4 weeks } \\
\text { Microsporum spp.: 4-6 weeks }\end{array}$ \\
\hline Ketoconazole & $4 \mathrm{mg} / \mathrm{kg} / \mathrm{day}$ & 12 weeks \\
\hline $\begin{array}{l}\text { Terbinafine tablets } \\
\text {-250 mg }\end{array}$ & $\begin{array}{l}\text { 4-6 mg/kg/day } \\
\text { 10-20 kg: } 62.5 \mathrm{mg} \\
\text { 20-40 mg: } 125 \mathrm{mg} \\
>40 \mathrm{~kg}: 250 \mathrm{mg}\end{array}$ & $\begin{array}{l}\text { T. tonsurans: } 2-6 \text { weeks } \\
\text { M. canis: } 8-12 \text { weeks }\end{array}$ \\
\hline $\begin{array}{l}\text { Terbinafine granules } \\
-125 \mathrm{mg} \text { and } 187.5 \mathrm{mg}\end{array}$ & $\begin{array}{l}<25 \mathrm{~kg}: 125 \mathrm{mg} \\
25-35 \mathrm{~kg}: 187.5 \mathrm{mg} \\
>35 \mathrm{~kg}: 250 \mathrm{mg}\end{array}$ & $\begin{array}{l}\text { FDA-approved for children } \geq 4 \text { years } \\
6 \text {-week duration for all species }\end{array}$ \\
\hline \multicolumn{3}{|l|}{ Oral solution } \\
\hline $\begin{array}{l}\text { Griseofulvin } \\
\text { microsized - (125 mg/5 mL) }\end{array}$ & $20-25 \mathrm{mg} / \mathrm{kg} /$ day & $\begin{array}{l}\geq 6 \text { weeks; continue until clinically } \\
\text { clear }\end{array}$ \\
\hline Itraconazole & $3 \mathrm{mg} / \mathrm{kg} / \mathrm{day}$ & 6 weeks \\
\hline Fluconazole & 3 to $6 \mathrm{mg} / \mathrm{kg} / \mathrm{day}$ & 3 weeks \\
\hline
\end{tabular}


Table 6

\begin{tabular}{|c|c|c|c|}
\hline Drug & Available as branded drug & $\underline{\text { Available as generic drug }}$ & $\begin{array}{l}\text { Approved for tinea capitis in } \\
\text { children (<18 years old) }\end{array}$ \\
\hline Griseofulvin & Brazil, Italy, India, USA & Italy, India, UK, USA & South Africa, Brazil, Italy, USA \\
\hline Terbinafine & $\begin{array}{l}\text { South Africa, Brazil, } \\
\text { Canada, Italy, India, USA }\end{array}$ & $\begin{array}{l}\text { Brazil, Canada, Italy, India, } \\
\text { UK, USA }\end{array}$ & $\begin{array}{l}\text { South Africa, Brazil, Canada, } \\
\text { USA }\end{array}$ \\
\hline Itraconazole & $\begin{array}{l}\text { South Africa, Brazil, } \\
\text { Canada, Italy, India, USA }\end{array}$ & $\begin{array}{l}\text { South Africa, Brazil, Canada, } \\
\text { Italy, India, UK, USA }\end{array}$ & South Africa, Brazil \\
\hline Fluconazole & $\begin{array}{l}\text { South Africa, Brazil, } \\
\text { Canada, Italy, India, USA }\end{array}$ & $\begin{array}{l}\text { South Africa, Brazil, Canada, } \\
\text { Italy, India, UK, USA }\end{array}$ & South Africa \\
\hline
\end{tabular}

Global paediatric drug availability ${ }^{55-59}$ 